\title{
Perencanaan Lanskap Konservasi Budaya Suku Baduy Luar dan Dangka dengan Pendekatan Bioregion
}

\author{
DEASNY PRATAMI ${ }^{1}$, QODARIAN PRAMUKANTO²*
}

1. Alumnus Departemen Arsitektur Lanskap, IPB, Indonesia

2. Staf Pengajar Departemen Arsitektur Lanskap, IPB, Indonesia

*E-mail: qpramukanto@gmail.com

\section{ABSTRACT \\ Landscape Planning for Cultural Conservation of Outter and Dangka Baduy Tribe with Bioregion Approach}

The Baduy Tribe is a community which preserves their own culture, tradition, and believe. The Baduy Tribe has suffered some external influence towards their culture, especially effecting the Outter Baduy and Dangka community which functions as buffer for the Inner Baduy region. The general purpose of this research is to plan a cultural conservation landscape for the Outter Baduy and Dangka Tribe base on bioregion approach. Bioregion constitutes the geographical area, which its delineation is not determine by administrative or political boundaries, instead its limited by the culture domain and the nature boundaries. The research consists of: preparation, preliminary study, analysis, synthesis, and planning. Analysis is done to determine the bioregion units. Evaluation was done by matching the bioregion characteristic of Inner Baduy with bioregion characteristic of Outter Baduy and Dangka. The evaluation result was utilise the to develop a concept to lead in the landscape planning to be developed. The bioregional based of planning concept has a purpose to improve the quality of life by combining nature as a resource and human need, through optimalization the environment sustainable. The final result is arranged as landscape planning for cultural landscape conservation of The Outter Baduy and Dangka Tribe.

Keywords: bioregion, landscape planning, Baduy tribe

\section{Pendahuluan}

Kehidupan masyarakat Baduy berorientasi pada alam, sehingga budaya yang berkembang dalam masyarakat sangat berhubungan dengan kondisi alam. Secara umum masyarakat Baduy dibagi menjadi tiga bagian yaitu tangtu, panamping, dangka. Tangtu dan panamping berada pada wilayah Desa Kanekes, sedangkan dangka ada yang berada di dalam dan di luar Desa Kanekes.

Suku Baduy telah mengalami pengaruh budaya dari luar, terutama pada Masyarakat Baduy Luar dan Dangka. Perubahan ini dapat dilihat dari bentuk pemanfaatan alam seperti hutan dan sungai. Perubahan pola penggunaan lahan merupakan ancaman bagi kelestarian budaya Suku Baduy. Padahal ketiga suku Baduy ini merupakan satu kesatuan wilayah adat, jika salah satu wilayah terancam, maka keseluruhan Baduy akan terancam juga. Oleh karena itu diperlukan upaya untuk mengkonservasi baik secara biofisik maupun budaya secara simultan. Bentuk perencanaan lanskap konservasi budaya Suku Baduy Luar dan Dangka dengan pendekatan bioregion dapat mengakomodasi kepentingan tersebut. 
Tujuan penelitian ini adalah merencanakan lanskap konservasi budaya Suku Baduy Luar dan Dangka dengan pendekatan bioregion melalui identifikasi dan analisis karakter bioregion Baduy Dalam, Luar dan Dangka, menyusun kriteria perencanaan konservasi berdasarkan karakter bioregion Baduy Dalam, serta menyusun rencana lanskap konservasi budaya Baduy Luar dan Dangka dengan pendekatan bioregion.

\section{Metodologi}

\section{Waktu dan Tempat Penelitian}

Penelitian ini dilakukan selama lima bulan (mulai Februari sampai Juni 2013). Lokasi penelitian adalah Kampung Cempaka Putih, Baduy Luar dan tiga Kampung Baduy Dangka yaitu Kampung Gajeboh, Marengo, dan Balimbing yang terdapat di dalam Desa Kanekes Kecamatan Lewidamar, Kabupaten Lebak, Propinsi Banten (Gambar 1).

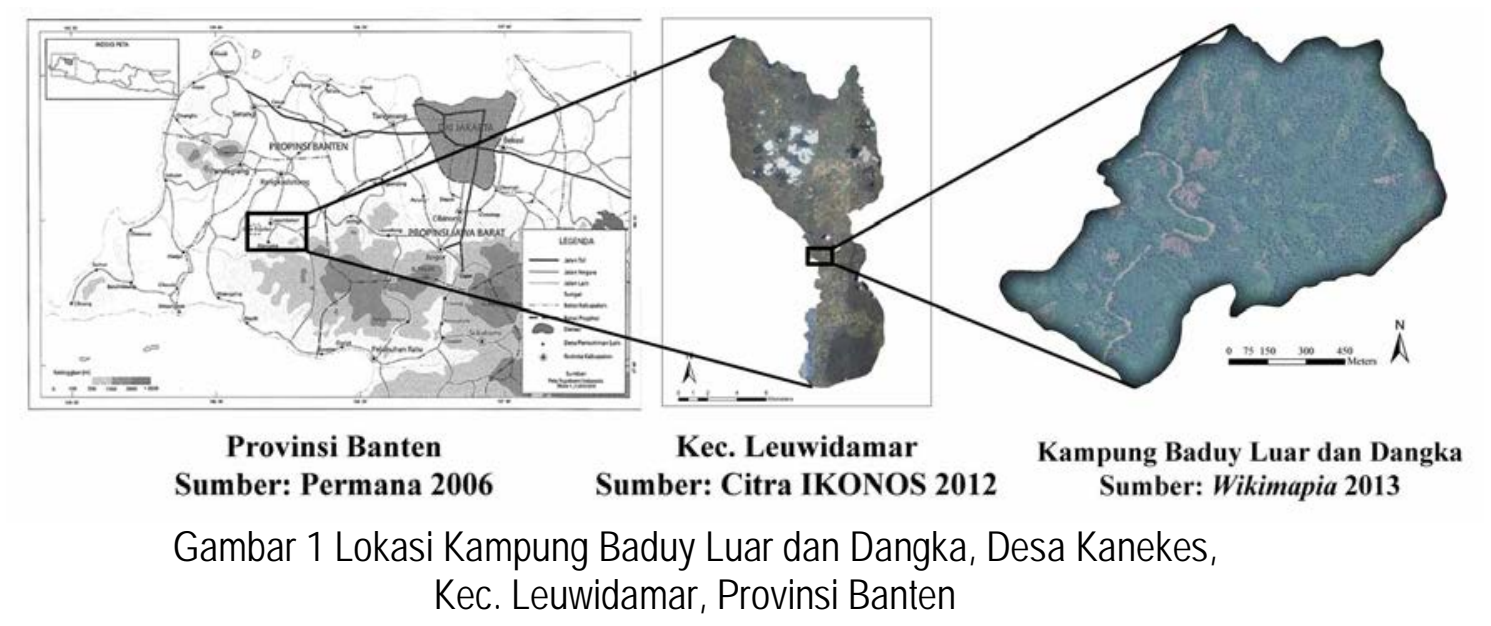

\section{Metode dan Tahapan Penelitian}

Penelitian ini dilakukan dengan metode survei lapang dan desk study, dengan tahapan: persiapan, preliminary study, inventarisasi, analisis, sintesis, dan perencanaan. Pada tahap persiapan dilakukan penetapan tujuan perencanaan, pengumpulan informasi awal, penyusunan proposal penelitian, dan perizinan melakukan penelitian. Pada tahap preliminary study dilakukan studi literatur terhadap penelitian dan studi yang pernah dilakukan untuk menyusun kriteria bio-fisik dan budaya dari Baduy Dalam berdasarkan kategori V dalam penentuan kawasan perlindungan menurut UNESCO (1972) dalam Phillips (1998) yaitu perlindungan lanskap/seascape. Tahap inventarisasi dilakukan melalui pengumpulan data primer diperoleh melalui survei, pengamatan langsung di lapang dan wawancara terhadap masyarakat (informant) yang memiliki pengaruh dalam komunitas Baduy. Data sekunder didapatkan melalui dinas terkait. Kemudian tahap analisis terdiri dari penyusunan data spasial dan atribut berupa karakteristik bio-fisik dan budaya dari Baduy Luar dan Dangka. Data ini digunakan pada analisis bioregional untuk menentukan unit bioregion, unit lanskap, dan unit tempat. Pada tahap sintesis dilakukan evaluasi dengan menyepadankan kriteria karakteristik bioregion Baduy Dalam dengan karakteristik bioregion yang terdapat pada Kampung Baduy Luar dan Dangka. Pada tahap perencanaan dilakukan pengajuan konsep perencanaan lanskap konservasi budaya, kemudian dilakukan pengembangan konsep perencanaan dan hasil akhirnya berupa gambar rencana lanskap konservasi budaya. Diagram tahapan penelitian dapat dilihat pada Gambar 2. 


\section{Hasil dan Pembahasan}

\section{Kondisi Umum}

Secara administratif Kampung Baduy Luar dan Dangka ini terletak di Desa Kanekes, Kecamatan Leuwidamar, Kabupaten Lebak, Provinsi Banten dengan luas 127,33 ha. Kampung Cempaka Putih merupakan salah satu Kampung Baduy Luar sedangkan Kampung Gajeboh, Marengo dan Balimbing merupakan tiga kampung Baduy Dangka yang terletak di wilayah tanah ulayat masyarakat Baduy. Kelembagaan secara adat di keempat kampung ini masing-masing dipimpin oleh Kokolot Lembur.

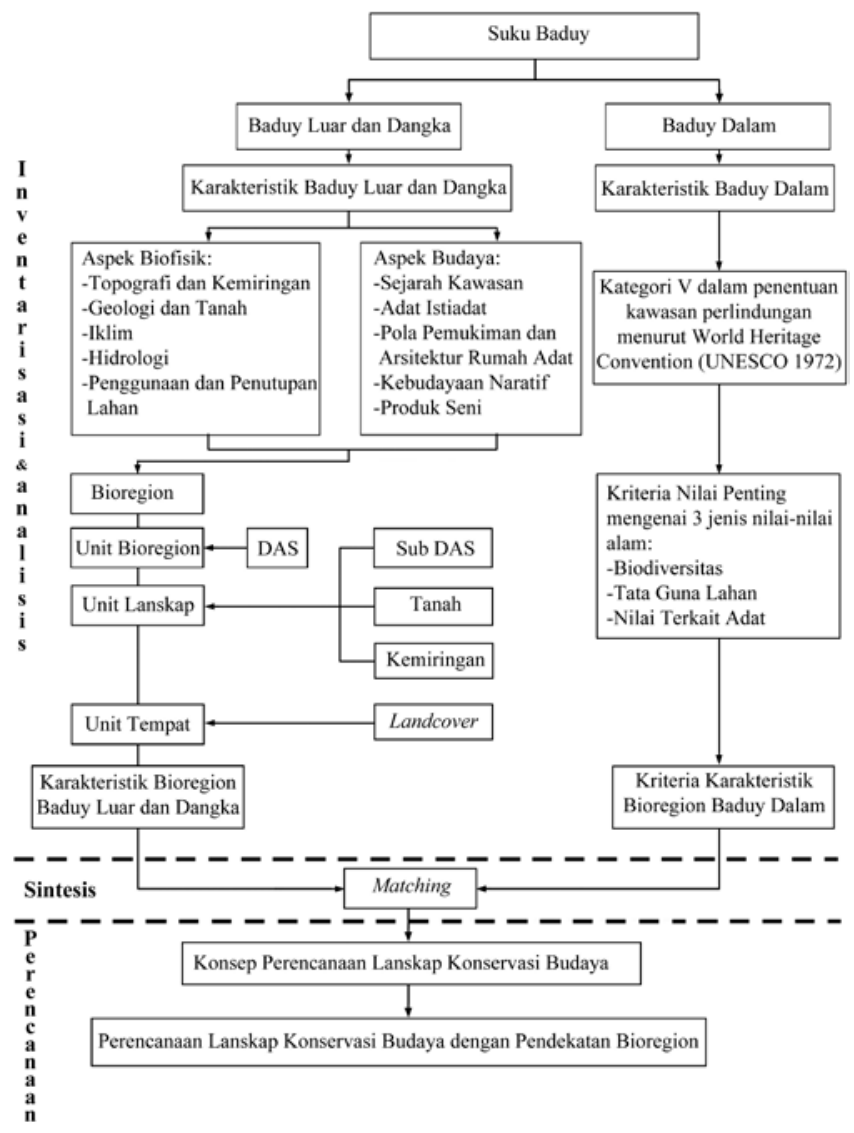

Gambar 2 Diagram Tahapan Penelitian

\section{Data dan Analisis}

\section{Karakteristik Bioregion Baduy Luar dan Dangka}

\section{Aspek Budaya}

Baduy berasal dari sebuah nama sungai tempo dulu, yaitu Sungai Cibaduy yang mengalir di sekitar tempat tinggal mereka dan berdasarkan nama salah satu bukit yang berada di kawasan tanah ulayat mereka yaitu Bukit Baduy (Kurnia dan Sihabudin 2013). Masyarakat Kampung Baduy Luar dan Dangka memiliki perilaku keseharian yang mengarah pada hidup sederhana dan hidup berpedoman pada aturan (pikukuh) dan kaidah-kaidah yang ada dalam masyarakat. Namun, dalam kehidupan sehari-harinya mereka diberikan kebijakan dalam melaksanakan ketentuan hukum adat.

Pemukiman di Kampung Baduy Luar dan Dangka terdiri atas sejumlah rumah (imah), bangunan tempat menumbuk padi (saung lisung), bangunan tempat menyimpan padi (leuit), dan lingkungan sekitarnya. Rumah Adat memiliki bentuk yang seragam yaitu berupa rumah panggung sederhana dan menghadap ke arah utara-selatan (nyulah 
nyanda). Ruang rumah panggung terdiri atas tepas, pendeng (kamar tidur), goah (gudang dan tempat menyimpan padi), tengah imah, parako (dapur), dan golodog (bagian belakang). Dalam pembangunan rumah, leuit, dan saung lisung masyarakat Baduy Luar dan Dangka menggunakan material lokal yang diambil dari leuweung lembur, reuma, dan leuweung kolot.

Kebudayaan naratif yang ada dalam masyarakat Baduy berupa pepatah Bahasa Sunda dan diperuntukkan untuk berbagai aspek kehidupan yaitu berupa pantun. Pantun dalam masyarakat baduy mendeskripsikan tempat tertentu yang menurut kepercayaan mereka tempat tersebut memiliki nilai yang perlu dijaga kelestariannya. Tempat tersebut yaitu pemukiman, leuweung lembur, leuweung kolot, dan sungai.

Produk seni yang ada di Kampung Baduy Luar dan Dangka sangat sederhana yaitu seni motif kain tenun, hulu dan sarung kemudian alat tenun, golok, alat musik, dan anyaman/rajutan. Alat musik yang mereka kenal adalah angklung, kecapi, gamelan, suling bambu, toleot (suling berukuran pendek), karinding, dan rendo. Anyaman atau rajutan yang khas dibuat oleh masyarakat Baduy adalah tas koja dan jarog. Bahan baku dalam membuat produk seni tersebut dibuat dengan menggunakan material lokal yang diambil dari leuweung lembur, reuma, dan leuweung kolot.

\section{Aspek Biofisik}

Kampung Baduy Luar dan Dangka memiliki ketinggian 225 sampai $425 \mathrm{~m}$ dpl. Kelas lereng ditentukan menjadi lima kelas berdasarkan kriteria penentuan kawasan lindung (SK Mentan No.837/Kpts/Um/ll/1980) yaitu 0-8\% (datar), 8-15\% (landai), 15-25 \% (agak curam), 25-40 $\%$ (curam), dan $>40 \%$ (sangat curam). Berdasarkan data BPDAS Citarum-Ciliwung (2010), bentuk (fisiografi) lahan di wilayah Kecamatan Leuwidamar yaitu zona Pegunungan Bayah yang berasal dari endapan vulkanik kwarter dan formasi batuan endapan permukaan aluvial (Qpv). Jenis tanahnya adalah latosol coklat yang memiliki distribusi kadar liat tinggi $(\geq 60 \%)$, remah sampai gumpal dan gembur. Menurut kepekaannya terhadap erosi, tanah latosol masuk dalam kriteria agak peka (SK Mentan No.837/Kpts/Um/l/1980).

Berdasarkan data iklim dari BMKG di Stasiun Curug, Banten dari tahun 2003 hingga tahun 2012, Kampung Baduy Luar dan Dangka memiliki suhu rata-rata $26,5{ }^{\circ} \mathrm{C}$, kelembaban udara rata-rata $81 \%$, dan curah hujan rata-rata bulanan yaitu $171,1 \mathrm{~mm}$ yang termasuk dalam kategori sedang. Kampung Baduy Luar dan Dangka termasuk dalam SubDAS Ciujung Hulu yang dilalui oleh aliran Sungai Ciujung. Pada penelitian ini, Kampung Baduy Luar dan Dangka terbagi menjadi 20 daerah tangkapan air (Sub DAS). Penentuan Sub DAS dilakukan dengan mendelineasi batas-batas punggung bukit (ridgelines) dari garis kontur yang terdapat pada peta topografi.

Pola penggunaan lahan di Kampung Baduy Luar dan Dangka dapat dibagi menjadi 6, yaitu pemukiman, hutan kampung (leuweung lembur), ladang (huma), kebun campuran (jami), hutan sekunder tua (reuma), dan hutan lindung (leuweung kolot). Penutupan lahan diklasifikasikan berdasarkan hasil interpretasi visual citra Ikonos dan survey lapang. Luas penutupan lahan Kawasan Kampung Baduy Luar dan Dangka dapat dilihat pada (Tabel 1).

Tabel 1 Luas Penutupan Lahan Kawasan Kampung Baduy Luar dan Dangka

\begin{tabular}{ccc}
\hline Penutupan Lahan & Luas (ha) & Persentase (\%) \\
\hline Pemukiman & 3,110 & 2,44 \\
Leuweung lembur & 14,054 & 11,04 \\
Huma & 5,572 & 4,38 \\
Jami & 7,837 & 6,15
\end{tabular}




\begin{tabular}{ccc}
\hline Penutupan Lahan & Luas (ha) & Persentase (\%) \\
\hline Reuma & 84,146 & 66,09 \\
Leuweung kolot & 9,402 & 7,38 \\
Badan Air & 3,211 & 2,52 \\
Total & 127,33 & 100,00 \\
\hline
\end{tabular}

Berdasarkan hasil survey dan wawancara, vegetasi yang dimanfaatkan berjumlah 65 spesies. Kelompok manfaat yang memiliki spesies vegetasi dalam jumlah besar adalah untuk sumber pangan, obat-obatan, dan bahan bangunan (Gambar 3). Jumlah pengambilan tanaman terbesar yaitu pada reuma, leuweung kolot, dan leuweung lembur (Gambar 4).

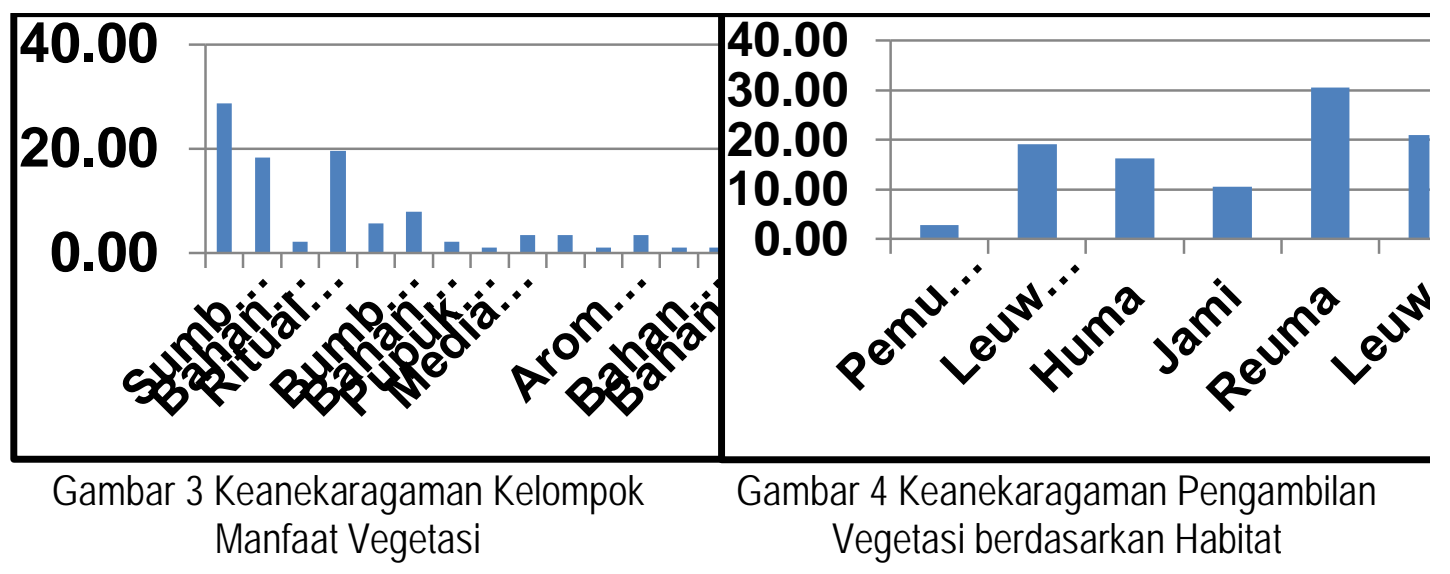

\section{Karakteristik Bioregion Baduy Dalam}

Karakteristik disusun berdasarkan kategori $\mathrm{V}$ dalam penentuan kawasan perlindungan menurut UNESCO (1972, dalam Phillips, 1998) yaitu perlindungan lanskap/seascape. Kategori $\mathrm{V}$ dalam kriteria nilai penting world heritage convention ini menjelaskan mengenai 3 (tiga) jenis nilai-nilai alam, yaitu:

1. Sumber daya biologi (Biodiversitas), yang berkaitan dengan kompromi dalam mempertahankan keragaman biologi alam dan pertanian.

2. Karakteristik pemanfaatan/penggunaan sumber daya alam oleh manusia, seperti penggunaan lahan yang berkelanjutan.

3. Aspek keterkaitan hubungan manusia dengan alam dan kelekatan nilai-nilai masyarakat dengan kualitas alam (lanskap).

Tabel 2 menguraikan karakteristik bioregion Baduy Dalam berdasarkan tiga kriteria UNESCO (1972) untuk kategori V. Karakteristik bioregion Baduy Dalam ini digunakan sebagai bahan untuk mengevaluasi karakteristik bioregion Baduy Luar dan Dangka.

Tabel 2 Karakteristik Bioregion Baduy Dalam

\begin{tabular}{ll}
\hline \multicolumn{1}{c}{ Kriteria Nilai Penting } & \multicolumn{1}{c}{ Karakteristik Bioregion Baduy Dalam } \\
\hline 1. Biodiversitas & - Keanekaragaman vegetasi leuweung kolot dan leuweung larangan memiliki \\
& keanekaragaman tinggi yaitu sebanyak 234 spesies (Iman, 2011) \\
& - Keanekaragaman vegetasi reuma memiliki keanekaragaman sedang yaitu sebanyak 114 \\
& spesies (Iman, 2011) \\
- & Keanekaragaman vegetasi leuweung lembur memiliki keanekaragaman sedang yaitu \\
& sebanyak 137 spesies (Iman, 2011) \\
& - Keanekaragaman vegetasi di lahan huma memiliki keanekaragaman rendah yaitu sebanyak \\
& 15 spesies.
\end{tabular}




\begin{tabular}{|c|c|}
\hline Kriteria Nilai Penting & Karakteristik Bioregion Baduy Dalam \\
\hline Pemukiman & $\begin{array}{l}\text { Menggunakan prinsip nyulah nyanda (utara-selatan) dan terbagi menjadi: Imah Puun } \\
\text { (selatan), Bale Adat (utara), Alun-alun (diantara imah puun dan bale adat), saung lisung } \\
\text { (utara), imah warga, leuit (utara, barat, selatan khusus leuit puun), pancuran (utara) }\end{array}$ \\
\hline Leuweung lembur & $\begin{array}{l}\text { - Leuweung lembur (hutan kampung) berada mengelilingi pemukiman dan dibudidayakan } \\
\text { vegetasi penghasil kayu, } \\
\text { buah, dan obat-obatan. } \\
\text { - Lahan ini berada pada lereng datar hingga landai dan terdapat lumbung padi (leuit) dan } \\
\text { area pemakaman. }\end{array}$ \\
\hline Huma & $\begin{array}{l}\text { - Lahan ini berada di lereng landai, curam, dan agak curam. } \\
\text { - Huma (ladang) di Baduy Dalam menurut pengelolaannya dibagi menjadi tiga macam yaitu } \\
\text { Huma Puun, Huma Tangtu, dan Huma Serang. } \\
\text { - Penanaman padi di ketiga huma dilakukan tidak serentak, penanaman padi pertama } \\
\text { dilakukan di Huma Puun, kemudian Huma Serang dan terakhir Huma Tangtu. } \\
\text { - Dalam proses penanaman padi, padi ditanam mengikuti garis kontur untuk mencegah erosi } \\
\text { tanah. }\end{array}$ \\
\hline Jami & $\begin{array}{l}\text { - Jami (kebun campuran) dibudidayakan jenis vegetasi penghasil bumbu dapur, sayuran, dan } \\
\text { buah-buahan yang digunakan untuk memenuhi kebutuhan rumah tangga warga Baduy. } \\
\text { - Lahan ini berada di lereng landai, curam, dan agak curam. }\end{array}$ \\
\hline Reuma & $\begin{array}{l}\text { - Reuma (hutan sekunder tua) dibudidayakan jenis vegetasi penghasil kayu, buah, dan obat- } \\
\text { obatan. Vegetasi tersebut sengaja dibudidayakan dan memiliki fungsi konservasi } \\
\text { keanekaragaman vegetasi dan satwa, sistem hidrologi dan tanah, fungsi ekonomi, sosial } \\
\text { dan budaya. } \\
\text { - Lahan ini berada di lereng landai, curam, dan agak curam. }\end{array}$ \\
\hline $\begin{array}{l}\text { Leuweung kolot dan } \\
\text { larangan }\end{array}$ & $\begin{array}{l}\text { - Leuweung larangan (hutan larangan) merupakan kawasan hutan yang tidak diperuntukan } \\
\text { sebagai huma. } \\
\text { - Lahan hutan ini berada di lereng landai, agak curam, curam, dan sangat curam. } \\
\text { - Hutan ini berada di bagian selatan Baduy dekat dengan Kampung Baduy Dalam. Dalam } \\
\text { hutan ini terdapat Sasaka Domas, sehingga disebut sebagai hutan sakral dan hanya orang } \\
\text { tertentu saja yang boleh masuk ke dalam hutan ini seperti Puun dan pejabat adat Baduy. }\end{array}$ \\
\hline \multicolumn{2}{|l|}{ 3. Nilai terkait adat } \\
\hline Hukum Adat & $\begin{array}{l}\text { - Ngahuma menjadi mata pencaharian wajib dengan menggarap huma serang, puun, dan } \\
\text { tangtu, dilarang menggunakan alat elektronik, alas kaki, deterjen, sabun, kendaraan, } \\
\text { poligami, perhiasan emas, dan membuka warung }\end{array}$ \\
\hline Upacara Adat & $\begin{array}{l}\text { - Ngalaksa, Kawalu, Seba, hajatan pernikahan dengan sistem dijodohkan, sunatan } \\
\text { dilaksanakan massal } \\
\text { - hanya } 2 \text { warna yaitu hitam dan putih, tidak dijahit menggunakan jarum, tidak menggunakan } \\
\text { kancing, wanita menggunakan kebaya dan selendang, laki-laki menggunakan sarung }\end{array}$ \\
\hline Kriteria Nilai Penting & Karakteristik Bioregion Baduy Dalam \\
\hline Arsitektur Rumah Adat & $\begin{array}{l}\text { - Bentuk arsitektur rumah adat yaitu rumah panggung, saat pembangunan kontur tanah tidak } \\
\text { diubah, tidak menggunakan paku dan alat modern, hanya terdapat satu pintu menghadap } \\
\text { utara/selatan dan tidak memiliki jendela, tata ruang rumah terdiri dari golodog, sosoro, } \\
\text { tepas, imah, dan parako. }\end{array}$ \\
\hline Naratif & $\begin{array}{l}\text { Pantun ini juga mendeskripsikan tempat tertentu yang perlu dijaga kelestariannya yaitu } \\
\text { pemukiman, leuweung lembur, leuweung kolot/larangan, dan sungai }\end{array}$ \\
\hline Produk Seni & $\begin{array}{l}\text { Produk seni yang dihasilkan yaitu kain tenun, alat tenun, hulu, surung, telekung, angklung, } \\
\text { kecapi, karinding, kumbang, tarawelet, kolecer, golok, tas koja, dan jarog. Produk dibuat } \\
\text { dengan material lokal dengan izin dari Puun. }\end{array}$ \\
\hline
\end{tabular}

\section{Analisis Bioregional \\ Unit Bioregion}

Secara hierarki klasifikasi unit bioregion Kampung Baduy Luar dan Dangka, diinisiasi melalui karakteristik wilayah tangkapan air (DAS). Unit bioregion Kampung Baduy Luar dan Dangka berada dalam (bagian) wilayah DAS Ciujung.

\section{Unit Lanskap}

Unit lanskap dalam penelitian ini ditentukan berdasarkan klasifikasi Sub DAS yang terdapat pada Kampung Baduy Luar dan Dangka. Terdapat 20 Sub DAS yang dapat 
dibedakan. Kemudian 20 Sub DAS tersebut didelineasi berdasarkan jenis tanah dan kemiringan lahan, sehingga unit lanskap yang terbentuk yaitu 79 unit lanskap (Gambar 5).

\section{Unit Tempat}

Unit tempat dalam bioregion menurut Kim et al (2000, dalam Pramukanto, 2004) merupakan hierarki terendah pada subdivisi bioregion. Unit terkecil dalam klasifikasi ini ditentukan berdasarkan penggunaan/penutupan lahan (landcover). Nilai intrinsik yang terkandung dalam unit tempat ini merupakan ekspresi dari unsur fisik (Sub DAS, Tanah, dan Lereng). Penutupan lahan dijadikan sebagai dasar dalam menentukan unit tempat karena penggunaan/penutupan lahan (landcover) dapat menggambarkan suatu aktivitas (budaya) pada Kampung Baduy Luar dan Dangka. Berdasarkan hasil analisis, Kampung Baduy Luar dan Dangka terdeleniasi menjadi 237 unit tempat (Gambar 6).

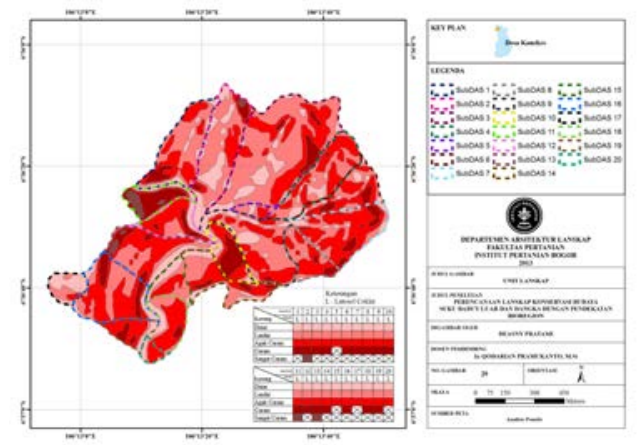

Gambar 5 Unit Lanskap Kampung Baduy Luar dan Dangka

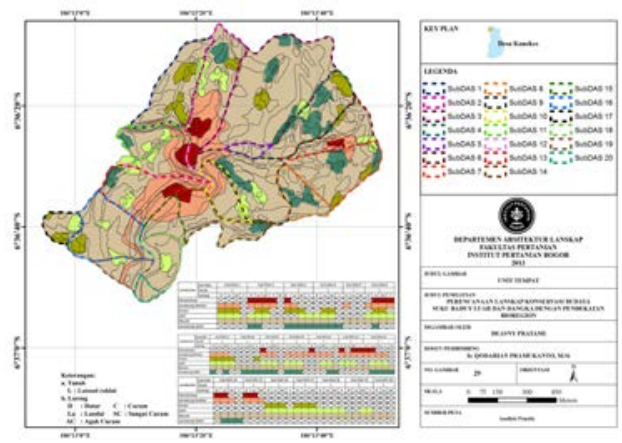

Gambar 6 Unit Tempat Kampung Baduy Luar dan Dangka

\section{Sintesis}

Pada tahap sintesis dilakukan evaluasi untuk menyepadankan kriteria karakteristik bioregion Baduy Dalam (Tabel 2) dengan karakteristik bioregion Baduy Luar dan Dangka. Usulan perbaikan hasil evaluasi karakteristik bioregion Baduy Luar dan Dangka dapat dilihat pada Tabel 3.

Tabel 3 Usulan Perbaikan Hasil Evaluasi Karakteristik Bioregion Baduy Luar dan Dangka

\begin{tabular}{|c|c|}
\hline Kriteria Nilai Penting & Usulan Perbaikan \\
\hline 1.Biodiversitas & $\begin{array}{l}\text { Membudidayakan kembali jenis vegetasi yang dapat memberikan manfaat ekologi, sosial, } \\
\text { ekonomi dan budaya sehingga pengetahuan masyarakat mengenai vegetasi tersebut dapat } \\
\text { terkonservasi. }\end{array}$ \\
\hline \multicolumn{2}{|l|}{ 2.Tata Guna Lahan } \\
\hline Pemukiman & $\begin{array}{l}\text { - Perluasan terhadap alun-alun agar kegiatan upacara adat kampung dapat tetap } \\
\text { dilaksanakan di lahan ini. } \\
\text { - Penataan posisi imah warga agar tidak menghalangi imah kokolot lembur. } \\
\text { - Penataan posisi imah warga di sebelah timur lebih sedikit dibandingkan barat. }\end{array}$ \\
\hline Leuwueng lembur & $\begin{array}{l}\text { Mempertahankan kondisi yang ada serta menambah budidaya vegetasi yang dapat } \\
\text { memberikan manfaat ekologi, ekonomi, sosial, dan budaya }\end{array}$ \\
\hline Huma & Tetap mempertahankan kondisi yang ada saat ini \\
\hline Jami & Tetap mempertahankan kondisi yang ada saat ini \\
\hline Reuma & $\begin{array}{l}\text { Tetap mempertahankan kondisi yang ada saat ini dan menambah budidaya vegetasi yang } \\
\text { dapat memberikan manfaat ekologi, ekonomi, sosial, dan budaya }\end{array}$ \\
\hline Leuweung kolot & $\begin{array}{l}\text { Tetap mempertahankan dan menjaga kondisi leuweung kolot sebagai hutan lindung di } \\
\text { Baduy Luar dan Dangka }\end{array}$ \\
\hline $\begin{array}{l}\text { Leuweung larangan } \\
\text { 3.Nilai terkait adat }\end{array}$ & Lahan ini tidak ada dalam Kawasan Baduy Luar dan Dangka \\
\hline Hukum Adat & $\begin{array}{l}\text { Membudidayakan vegetasi penghasil sabun seperti Areuy leuksa dan Ki caang sehingga } \\
\text { penggunaan sabun, odol, dan deterjen dapat dikurangi }\end{array}$ \\
\hline Upacara Adat & Kelonggaran adat masih diperbolehkan karena tidak menyebabkan dampak terhadap \\
\hline
\end{tabular}




\begin{tabular}{ll}
\hline \multicolumn{1}{c}{ Kriteria Nilai Penting } & \multicolumn{1}{c}{ Usulan Perbaikan } \\
\hline \multirow{3}{*}{ Pakaian Adat } & lingkungan yang ada di Kawasan Baduy Luar dan Dangka \\
& Membudidayakan jenis vegetasi yang dapat memberikan fungsi sebagai pewarna alami \\
& untuk pakaian. Membudidayakan vegetasi bahan baku untuk membuat tenun (Hasman dan \\
& Reiss, 2012), yaitu kapas mori yang dihasilkan oleh jenis tanaman kapas yang tumbuh tinggi \\
& dengan produksi serat yang lebih banyak dan kapas leutik yang berasal dari jenis tanaman \\
& kapas yang lebih pendek dengan serat yang lebih halus. \\
Arsitektur Rumah Adat & - Membudidayakan jenis vegetasi penghasil kayu dan bambu yang digunakan sebagai \\
& bahan baku dalam pembuatan rumah \\
& - Penataan posisi imah agar tidak menghalangi imah kokolot lembur \\
& - Penataan imah di sisi timur lebih sedikit dari bagian barat \\
& \\
Naratif & Tetap mempertahankan pantun sebagai alat pengajar orangtua pada anaknya agar nilai \\
Produk Seni & adat dapat berkelanjutan \\
& Membudidayakan jenis vegetasi yang digunakan sebagai bahan baku produk seni, seperti \\
& Awi temen yang dijadikan sebagai bahan baku membuat angklung \\
\hline
\end{tabular}

\section{Konsep Dan Pengembangan \\ Konsep Perencanaan}

Berdasarkan pendekatan bioregion, Kampung Cempaka Putih, Gajeboh, Marengo, dan Balimbing yang terdiri atas 237 unit tempat selanjutnya diklasifikasikan berdasarkan kesamaan kondisi bioregionnya, sehingga dihasilkan block plan (Gambar 7) yang merepresentasikan sebaran 6 (enam) unit tempat. Konsep dasar perencanaan yang diterapkan di keempat Kampung Baduy Luar dan Dangka ini adalah membuat kawasan ini berkelanjutan baik secara ekologi, sosial, ekonomi, dan budaya melalui tindakan konservasi.

\section{Rencana Pengembangan Konsep}

\section{Konsep Ruang}

Model tata ruang Baduy Luar dan Dangka dikembangkan berdasarkan pada prinsip ruang menurut adat istiadat yang digunakan masyarakat Baduy pada umumnya yaitu utara-selatan (nyulah nyanda).

\section{Konsep Sirkulasi}

Konsep sirkulasi yang dikembangkan untuk Kampung Baduy Luar dan Dangka didasarkan pada prinsip yang berlaku dalam adat istiadat mereka. Jalan utama merupakan akses penghubung antar kampung berorientasi utara-selatan berupa jalan setapak. Hierarki jalur berikutnya yaitu jalan penghubung yang menghubungkan antarr uang yang ada dalam kawasan.

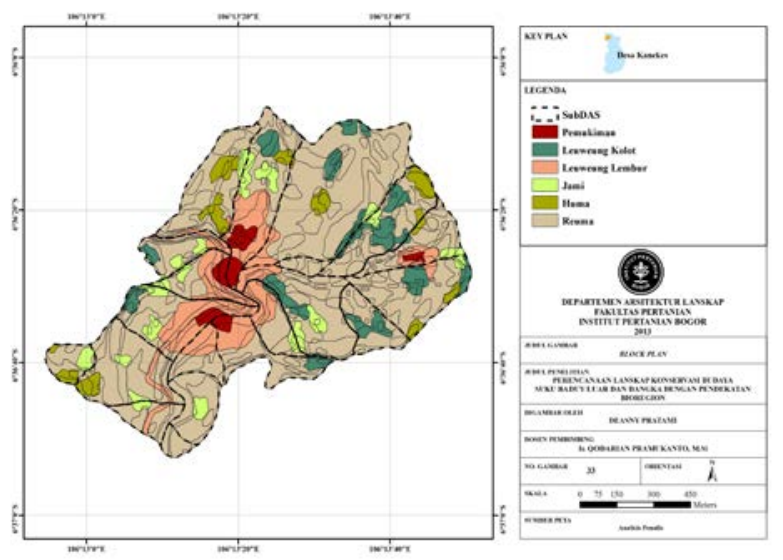

Gambar 7 Block plan 


\section{Konsep Vegetasi}

Tipe Vegetasi pada leuweung lembur yang mengelilingi pemukiman ini sering dibudidayakan dengan vegetasi semusim dan tahunan yang terdiri dari semak, pohon, penutup tanah. Sedangkan tipe vegetasi yang diprioritaskan untuk kegiatan perladangan (Huma) yaitu tanaman pangan seperti padi gogo dan palawija. Pada lahan ini dapat dilakukan penanaman tanaman penghasil sayuran, buah dan bumbu dapur. Untuk tipe vegetasi yang dibudidayakan di lahan Jami yaitu tanaman penghasil sayuran, bumbu dapur, dan buah-buahan yang terdiri dari jenis semak dan pohon. Tipe Vegetasi yang dibudidayakan di lahan Reuma yaitu vegetasi tahunan, terdiri dari semak (seperti Hanjuang/Cordyline terminalis, Harendong/Melastoma malabathricum, Jawer Kotok/Plectranthus scutellarides dan Kacapiring/Gardenia augusta), pohon sedang (Saga/Cayratia japónica, Kiray/Metroxylon sagu, Balimbing wuluh/Averrhoa bilimbi), dan pohon tinggi (Teureup/Artocarpus elastica, Saka/Schefflera longifolia, Peuteuy/Parkia speciosa, Mahoni/Swietenia macrophylla dan Picung/Pangium edule) yang dimanfaatkan untuk kepentingan bahan bangunan, bahan ritual adat, bahan obat-obatan tradisional, industri rumah tangga, dan kerajinan rumah tangga. Pada Leuweung Kolot, vegetasi yang ditanam berupa tanaman tahunan difokuskan untuk fungsi konservasi tinggi. Jenis-jenis vegetasi tersebut terdiri atas semak (seperti Harendong/Melastoma malabathricum dan Areuy amis mata/Ficus montana), pohon rendah (seperti Berenuk/Crescentia cujete, Bingbin/Pinanga coronata), pohon sedang (seperti Awi Apus/Gigantochloa apus, Awi Gede/Gigantochloa pseudoarundinacea dan Picung/Pangium edule), dan pohon tinggi (seperti Bayur/Pterospermum javanicum, Binglu/Mangifera caesia, dan Gintung/Bischofia javanica).

\section{Perencanaan Lanskap}

Pada tahap perencanaan lanskap dilakukan penuangan hasil akhir berupa gambar rencana lanskap. Gambar rencana lanskap dibuat berdasarkan block plan (Gambar 7) dan usulan perbaikan yang ada pada Tabel 3. Rencana lanskap konservasi budaya Suku Baduy Luar dan Dangka dapat dilihat pada Gambar 8.

Rencana ruang dibuat berdasarkan tata guna lahan yang berlaku di Baduy Luar dan Dangka. Terdapat enam ruang yaitu pemukiman, leuweung lembur, huma, jami, reuma, dan leuweung kolot. Keenam ruang tersebut penting untuk dikonservasi karena sangat terkait dengan budaya yang ada di atasnya.

Rencana sirkulasi dikembangkan mengikuti pengembangan konsep sirkulasi sebelumnya dengan membagi jalur sirkulasi menjadi dua, yaitu jalur utama (jalur yang menghubungkan antar kampung berorientasi utara-selatan dilalui oleh pejalan kaki dengan lebar jalan sebesar 2-3 m) dan jalur penghubung (jalur yang menghubungkan antar ruang yang ada dalam kawasan dilalui pejalan kaki dengan lebar jalan sebesar 1-2 meter).

Rencana vegetasi yang dikembangkan mengikuti pengembangan konsep vegetasi sebelumnya. Berdasarkan usulan perbaikan dari hasil evaluasi karakteristik Baduy Luar dan Dangka (Tabel 3), rencana vegetasi yang dikembangkan untuk Baduy Luar dan Dangka sebanyak 136 jenis vegetasi. 


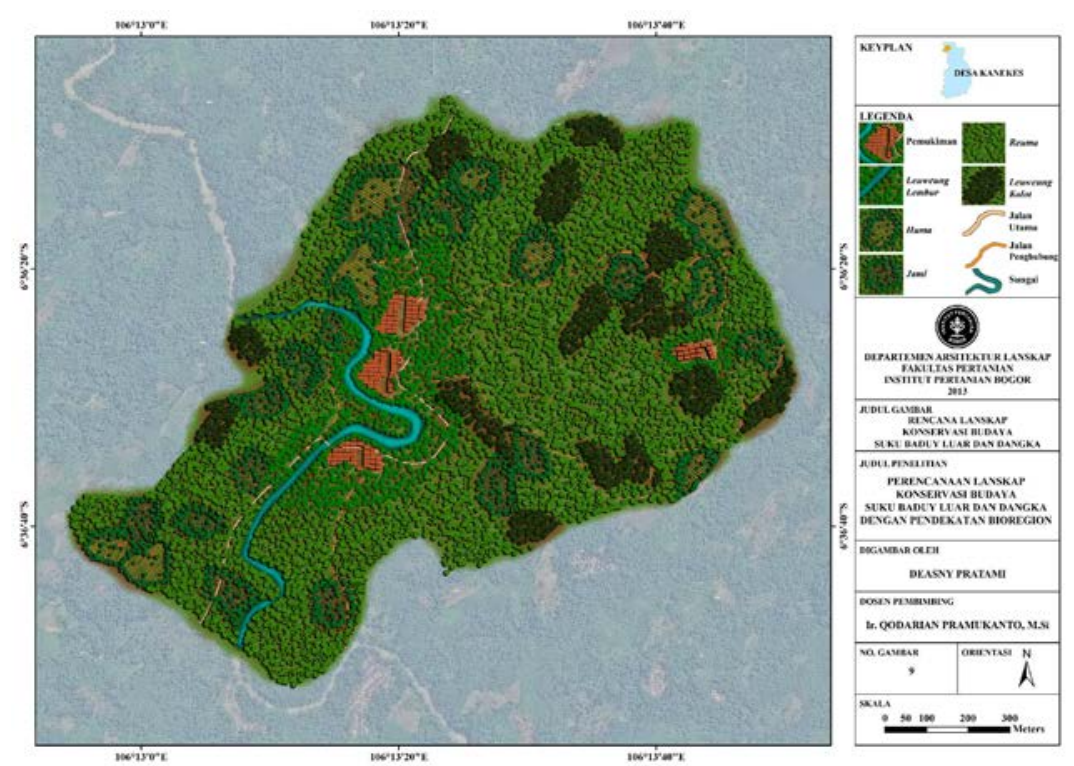

Gambar 8. Rencana Lanskap Konservasi Budaya Suku Baduy Luar dan Dangka

\section{Simpulan dan Saran}

\section{Simpulan}

1. Lanskap Baduy Luar dan Dangka khususnya di kawasan Kampung Cempaka Putih, Gajeboh, Marengo, dan Balimbing memiliki karakteristik lanskap berupa biofisik dan budaya yang membentuk unit-unit bioregion. Berdasarkan hasil analisis terhadap kawasan, kampung tersebut termasuk dalam unit bioregion dari DAS Ciujung yang dapat dibagi menjadi 237 unit tempat berdasarkan nilai intrinsik fisik (sub DAS, jenis tanah, dan lereng) dan nilai intrinsik sosial yaitu landcover yang menggambarkan interaksi biofisik dan budaya pada Kampung Baduy Luar dan Dangka.

2. Kriteria perencanaan dapat disusun berdasarkan karakteristik bioregion Baduy Dalam yang digunakan dalam evaluasi tata ruang Baduy Luar dan Dangka. Kriteria perencanaan dibangun berdasarkan kategori $\mathrm{V}$ penentuan kawasan perlindungan menurut World Heritage Convention (UNESCO 1972) yaitu tentang perlindungan Lanskap/Seascape.

3. Berdasarkan evaluasi karakteristik bioregion Baduy Luar dan Dangka (kawasan Kampung Cempaka Putih, Gajeboh, Marengo, dan Balimbing) yang dipadankan dengan karakteristik bioregion Baduy Dalam dapat disusun rencana lanskap konservasi Budaya. Rencana lanskap yang dituangkan berupa rencana ruang, rencana sirkulasi, dan rencana vegetasi.

\section{Saran}

Perencanaan lanskap konservasi budaya Suku Baduy Luar dan Dangka dengan pendekatan bioregion dapat menjadi jaminan bagi kelestarian budaya yang berlangsung dalam kawasan tersebut. Kelestarian kawasan dapat didukung juga dengan kerja sama yang baik antara pemerintah daerah dan masyarakat adatnya.

\section{Daftar Pustaka}

[BPDAS Citarum-Ciliwung] Badan Pengelolaan Daerah Aliran Sungai Citarum Ciliwung. 2010. Dokumen Rencana Pengelolaan DAS Terpadu DAS Ciujung. Bogor. 
Hasman, D. dan F. Reiss. 2012. Urang Kenekes, Baduy People. Indonesian Heritage Society. Jakarta

Iman, S.N. 2011. Penggunaan Pengetahuan Etnobotani dalam Pengelolaan Hutan Adat Baduy [Skripsi]. Institut Pertanian Bogor. Bogor.

Iskandar, J. 2012. Ekologi Perladangan Orang Baduy. P.T. Alumni. Bandung.

Kurnia, A., dan A. Sihabudin. 2013. Saatnya Baduy Bicara. Bumi Aksara. Serang.

Permana, R.C.E. 2006. Tata Ruang Masyarakat Baduy. Wedatama Widya Sastra. Jakarta.

Phillips A. 1998. The Nature of Cultural Landscape - a nature conservation perspective. Landscape Res., 23(1): 21 - 37.

Pramukanto, Q. 2004. Pemberdayaan Ruang Publik: Kesetangkupan Wilayah Biofisik dan Domain Masyarakat. Makalah Semiloka "Pemberdayaan Area Publik di dalam Kota, Area Publik sebagai Tempat Warga Kota Mengekspresikan Diri". Ikatan Arsitek Indonesia (IAI). Jakarta.

Wikimapia. 2013. Kampung Baduy. Terhubung berkala pada http://wikimapia.org/\#lang=en\&lat= 6.608520\& lon=106.223084\&z=17\&m=bh. [Diakses 22 Juli 2013] 